\title{
Az ómega-3 zsírsavak pótlásának klinikai értéke krónikus obstruktív tüdőbetegségben
}

\author{
Fekete Mónika dr. ${ }^{1}$. Szőllősi Gergö ${ }^{2}$ \\ Németh Anna Noémi ${ }^{1}$ - Varga János Tamás dr. ${ }^{3}$ \\ 'Semmelweis Egyetem, Általános Orvostudományi Kar, Népegészségtani Intézet, Budapest \\ ${ }^{2}$ Debreceni Egyetem, Népegészségügyi Kar, Családorvosi és Foglalkozás-egészségügyi Tanszék, Debrecen \\ ${ }^{3}$ Országos Korányi Pulmonológiai Intézet, Budapest
}

Bevezetés: Civilizált világunk, miközben látszólag túltáplált, ómega-3-hiányban szenved. A hosszú szénláncú, többszörösen telítetlen zsírsavak számos anyagcsere-megbetegedés (például elhízás, 2-es típusú diabetes mellitus, szív- és érrendszeri megbetegedések) kialakulásában játszhatnak szerepet. A halolajban lévő zsírsavak erôsítik az immunrendszert, csökkentik a koleszterin- és trigliceridszintet, csökkentik a gyulladást.

Célkitüzés: Vizsgálatunk célja a többszörösen telítetlen zsírsavak bevitelének monitorozása, valamint a tüdőfunkcióval és az életminőséggel való kapcsolatuk értékelése krónikus obstruktív tüdőbetegségben (COPD).

Módszer: Kérdőívünket az Országos Korányi Pulmonológiai Intézet Légzésrehabilitációs Osztályán, 2019. március 1. és 2020. március 1. között 40 év feletti COPD-s betegek körében vettük fel. Az életminőség mérésére a betegségspecifikus Szent György Légzési Kérdőívet alkalmaztuk, a légzésfunkciós és antropometriai adatokat az egészségügyi elektronikus nyilvántartási rendszerből nyertük ki.

Eredmények: A betegek medián életkora 66 (IQR 60-73) év volt, a nemek közötti megoszlást tekintve 47,5\% férfi és 52,5\% nő. A medián BMI 26,0 (IQR 21,7-30,6) kg/m², a FEV 1 (ref\%) 48,0 (IQR 38,1-55,3) volt. Az ómega-3 zsírsavakat a betegek $4,7 \%$-a $(\mathrm{n}=19)$ szedi rendszeresen, elsősorban kezelőorvosa javaslatára, a javasolt napi dózisban $(0,25-0,50 \mathrm{~g} / \mathrm{nap})$. Esetükben jobb életminőséget tapasztaltunk $(65,8[52,4-79,7]$ vs. $72,2[56,2-88,6] ; \mathrm{p}=0,044)$, kevesebb társbetegséggel rendelkeztek (hypertonia: 10 [52,6\%] vs. $275[72,1 \%] ; p=0,066$ ), kevesebb gyógyszert használtak (gyors hatású béta-2-agonista: 5 [25,3\%] vs. 197 [51,7\%]; p = 0,031), alacsonyabb volt a fellángolások száma (1 [1-3] vs. 2 [1-4]; p = 0,029), és nagyobb volt a 6 perces sétatávolság (300 [177-387] vs. 251 [150-345]; $\mathrm{p}=0,121)$.

Következtetés: Eredményeink arra utalnak, hogy a többszörösen telítetlen zsírsavak bevitele összefüggésben lehet az életminőséggel COPD-s betegekben. Vizsgálatunk szerint a betegek ómega-3-bevitele nem kielégítő - eredményeink alapján szeretnénk felhívni a figyelmet e zsírok fogyasztásának fontosságára.

Orv Hetil. 2021; 162(1): 23-30.

Kulcsszavak: krónikus obstruktív tüdőbetegség, ómega-3, eikozapentaénsav, dokozahexaénsav, életminőség

\section{Clinical value of omega-3 polyunsaturated fatty acid supplementation in chronic obstructive pulmonary disease}

Introduction: Our civilized world, while seems to be overweight, suffers from omega-3 deficiency. Long-chain polyunsaturated fatty acids can play a role in the development of many metabolic diseases (e.g., obesity, type 2 diabetes mellitus, cardiovascular disease). Fatty acids in fish oil strengthen the immune system, reduce cholesterol and triglyceride levels, have been proven to be beneficial, reduce inflammation.

Objective: The aim of our study was to monitor the intake of polyunsaturated fatty acids and to evaluate their relationship with lung function and quality of life in patients with chronic obstructive pulmonary disease (COPD).

Method: Our questionnaire was completed at the Department of Pulmonary Rehabilitation of the National Koranyi Institute for Pulmonology between March 1, 2019 and March 1, 2020 among COPD patients over 40 years of age. We used the disease-specific St. George's Respiratory Questionnaire to measure the quality of life; the respiratory function and anthropometric data were extracted from the electronic health record system.

Results: The median age of the patients was 66 (IQR 60-73) years, with a gender division of $47.5 \%$ male and $52.5 \%$ female. The median BMI was 26.0 (IQR 21.7-30.6) kg/m², and the median FEV (\%pred) was 48.0 (IQR 38.1-55.3). 
In the form of a dietary supplement, $4.7 \%(\mathrm{n}=19)$ of patients take omega-3 fatty acids regularly, mainly on the recommendation of their doctor, at the recommended daily dose $(0.25-0.50 \mathrm{~g} /$ day $)$. Among them, we detected a better quality of life $(65.8$ [52.4-79.7] vs. 72.2 [56.2-88.6]; $\mathrm{p}=0.044)$, had fewer comorbidities (hypertension: $10[52.6 \%]$ vs. $275[72.1 \%] ; \mathrm{p}=0.066$ ), consumed fewer drugs (short-acting bronchodilators: 5 [25.3\%] vs. 197 $[51.7 \%] ; \mathrm{p}=0.031)$, had fewer exacerbations $(1[1-3]$ vs. $2[1-4] ; \mathrm{p}=0.029)$, and higher six-minute walking distance $(300$ [177-387] vs. 251 [150-345]; $\mathrm{p}=0.121)$.

Conclusion: Our results suggest that the intake of polyunsaturated fatty acids may be related to the quality of life in COPD patients. According to our study, the intake of omega- 3 in patients is unsatisfactory, and based on our results, we would like to draw attention to the importance of consuming these fats.

Keywords: chronic obstructive pulmonary disease, omega-3, eicosapentaenoic acid, docosahexaenoic acid, quality of life

Fekete M, Szőllősi G, Németh AN, Varga JT. [Clinical value of omega-3 polyunsaturated fatty acid supplementation in chronic obstructive pulmonary disease]. Orv Hetil. 2021; 162(1): 23-30.

(Beérkezett: 2020. június 28.; elfogadva: 2020. július 15.)

\begin{abstract}
Rövidítések
$6 \mathrm{MWD}=(6$-minute walking distance $) 6$ perces sétatávolság; apoCIII $=$ apolipoprotein-CIII; BMI $=($ body mass index $)$ test tömegindex $;$ COPD $=($ chronic obstructive pulmonary disease $)$ krónikus obstruktív tüdőbetegség; CRP = C-reaktív protein; $\mathrm{DHA}=($ docosahexaenoic acid $)$ dokozahexaénsav; EPA $=($ eicosapentaenoic acid) eikozapentaénsav; $\mathrm{FEV}_{1}=$ (forced expiratory volume in the first second) erőltetett kilégzés első másodpercében kifújt volumen; $\mathrm{FVC}=$ (forced vital capacity) eróltetett kilégzési vitálkapacitás; GOLD $=($ Global Initiative for Chronic Obstructive Lung Disease) a COPD ellen küzdő nemzetközi ajánlás; HDL = (high-density lipoprotein $)$ magas sűrüségû lipoprotein; hs-CRP $=($ highly sensitive $\mathrm{CRP}$ ) nagy érzékenységú CRP; IL-6 = interleukin-6; IL-8 = interleukin-8; $\mathrm{IQR}=$ (interquartile range) interkvartilis tartomány; $\mathrm{LDL}=$ (low-density lipoprotein) alacsony sűrüségú lipoprotein; mMRC $=$ (modified Medical Research Council Questionnaire) a Brit Mellkasi Társaság módosított nehézlégzésskálája; PUFA $=$ (polyunsaturated fatty acids) többszörösen telítetlen zsírsavak; SGRQ-C = (St. George's Respiratory Questionnaire for COPD patients) Szent György Légzési Kérdőív COPD-s betegek számára; TNF $\alpha=$ tumornekrózisfaktor-alfa; TUKEB $=$ Tudományos és Kutatásetikai Bizottság; VLDL $=($ very-low-density lipoprotein) nagyon alacsony sűrűségű lipoprotein
\end{abstract}

A krónikus obstruktív tüdőbetegség (COPD) irreverzibilis légúti szúkülettel és krónikus légúti gyulladással járó kórkép, amely jelentős egészségügyi problémát jelent világszerte [1]. Az Egészségügyi Világszervezet tanulmánya szerint a COPD prevalenciája folyamatosan nő, és 2020-ra várhatóan a harmadik vezetô halálok lesz a világon [2]. Bár a COPD patomechanizmusa jelenleg sem ismert minden részletében, az elmúlt évtizedben kórfolyamatának felderítésében számos elörelépés történt. A kutatók úgy gondolják, hogy az oxidatív stressz fontos szerepet játszhat a COPD patogenezisében, nemcsak a közvetlen káros hatások révén, hanem a tüdőgyulladást szabályozó molekuláris mechanizmusokban való részvétel miatt is [3]. Ezek alapján felmerül, hogy az antioxi- dáns-terápia vagy az intenzíven antioxidánsokat tartalmazó étrend befolyásolhatja a gyulladásos folyamatot és a COPD progresszióját. A többszörösen telítetlen zsírsavak bizonyítottan csökkentik a vérben a gyulladásos paramétereket (C-reaktív protein [CRP], interleukin-6 [IL-6], interleukin-8 [IL-8], tumornekrózisfaktor-alfa $[\mathrm{TNF} \alpha])[4]$, ezenkívül a sejtmembrán összetételének megváltoztatása útján mérséklik a hypoxia okozta pulmonalis vasoconstrictiót, illetve a hypertensio mértékét is [5]. Egy kutatás szerint COPD-s betegek 8 héten át napi 9,0 g ómega-3-kiegészítést kaptak, és ennek hatására nőtt a betegek fizikai teljesítőképessége [6]; egy másik kutatás szerint a COPD-s betegek légúti tünetei javultak, mert bronchodilatator hatásúnak bizonyultak az ómega-3 zsírsavak [7]. Az American Dietetic Association által javasolt PUFA (többszörösen telítetlen zsírsavak) beviteli értéke napi >0,5 g EPA (eikozapentaénsav) + DHA (dokozahexaénsav) [8], ehhez képest rendkívüli mértékben alacsony az átlagos napi EPA + DHA bevitel a COPD-s betegek körében (átlag \pm SD [szórás]: $0,11 \pm$ $0,21 \mathrm{~g}$; nőknél: $0,1 \pm 0,1 \mathrm{~g}$ és férfiaknál $0,12 \pm 0,3 \mathrm{~g}$ ) [7]. Jelen tanulmányunk célja azon COPD-s betegek azonosítása, akiknél szerepel az ómega-3 esszenciális zsírsavak pótlása, valamint összefüggés keresése és értékelése a betegség súlyossága, a légzésfunkció, a betegek életminősége, társbetegségei, fizikai aktivitása és gyógyszerfelhasználása között. A kapott eredményekkel segítséget kívánunk nyújtani a betegeket kezelő szakembereknek a kezelés hatékonyságának megítéléséhez, és szeretnénk rávilágítani a táplálkozási területeken indokolt intervenció szükségességére.

\section{Módszer}

Az adatgyújtés önkéntes résztvevőkkel, anonim módon, önkitöltéses, papíralapú kérdőívek segítségével történt 2019. március 1. és 2020. március 1. között az Országos Korányi Pulmonológiai Intézet Légzésrehabilitációs 
Osztályán fekvő betegek körében. A vizsgálatban 400, 40 év feletti COPD-s beteg vett részt. A kérdőív kitöltése előtt a betegek részletes tájékoztatást kaptak a felmérés céljáról, idejéról, az anonim és összesített adatfeldolgozásról, a kutatás lényegéről. A vizsgálatot a TUKEB (Tudományos és Kutatásetikai Bizottság) jóváhagyta (engedélyszám: TUKEB 44402-2/2018/EKU); a kutatás megfelel a Helsinki Deklarációban foglaltaknak. A kutatásban részt vevők nem részesültek sem anyagi, sem egyéb díjazásban vagy juttatásban. Minden egyes betegnél megmértük a post-bronchodilatator $\mathrm{FEV}_{1}$ (eróltetett kilégzés első másodpercében kifújt volumen) értékét, és a becsült értékek százalékában fejeztük ki. A betegeket a GOLD (Global Initiative for Chronic Obstructive Lung Disease (a COPD nemzetközi ajánlása) szerinti A-D stádiumba soroltuk az aktuális és a jövőbeli kockázat paraméterei alapján a spirometriás értékek, a tünetek és az exacerbatiós ráta szerint (1. táblázat) [9].

$\mathrm{Az}$ életminőség mérésére a betegségspecifikus Szent György Légzési Kérdőív (SGRQ-C) [10] magyar nyelvre validált változatát használtuk, mely 40 kérdést tartalmaz. Az SGRQ-C az életminőséget befolyásoló tényezőket három kategóriába osztva vizsgálja: tüneti, aktivitási és a

1. táblázat |A krónikus obstruktív tüdőbetegség GOLD súlyossági stádiumai [9]

\begin{tabular}{|c|c|c|c|}
\hline $\begin{array}{l}\text { (C) } \\
\text { Magas kockázat } \\
\text { Kevés tünet }\end{array}$ & $\begin{array}{l}\text { (D) } \\
\text { Magas kockázat } \\
\text { Több tünet }\end{array}$ & $\begin{array}{l}\geq 2 \\
\text { vagy } \\
1 \text { kórházi }\end{array}$ & \multirow{2}{*}{$\begin{array}{l}\text { Exacer- } \\
\text { batiók } \\
\text { száma az } \\
\text { elmúlt 1 } \\
\text { évben }\end{array}$} \\
\hline $\begin{array}{l}\text { (A) } \\
\text { Alacsony kockázat } \\
\text { Kevés tünet }\end{array}$ & $\begin{array}{l}\text { (B) } \\
\text { Alacsony kockázat } \\
\text { Több tünet }\end{array}$ & $\begin{array}{l}1 \\
0\end{array}$ & \\
\hline $\begin{array}{l}\text { mMRC: } 0-1 \\
\text { CAT<10 }\end{array}$ & $\begin{array}{l}m M R C \geq 2 \\
C A T \geq 10\end{array}$ & & \\
\hline
\end{tabular}

CAT = COPD-értékelési teszt; GOLD = a COPD ellen küzdő nemzet közi ajánlás; $\mathrm{mMRC}=$ a Brit Mellkasi Társaság módosított nehézlégzésskálája

2. táblázat Az mMRC-kérdőív: a dyspnoe súlyosságának megítélése COPD-ben [12]

Fokozatok A nehézlégzést kiváltó fizikai terhelés foka

0. Csak megeróltető terhelésre fullad.

1. Nehézlégzés, ha siet, vagy enyhe emelkedőn megy felfelé.

2. Vízszintes talajon a vele egykorúaknál lassabban megy nehézlégzés miatt, vagy saját ütemű séta során is meg kell állnia légszomj miatt.

3. Vízszintesen haladva 100 m vagy néhány perc után meg kell állnia nehézlégzés miatt.

4. Az öltözködés nehézlégzést vált ki, vagy a lakását sem tudja elhagyni a légszomj miatt.

COPD = krónikus obstruktív tüdőbetegség; $\mathrm{mMRC}=\mathrm{a}$ Brit Mellkasi Társaság módosított nehézlégzésskálája tüdőbetegség mindennapi életre gyakorolt hatását vizsgáló szegmens. Az egyes válaszok súlyszámértéke alapján számolhatók a különböző dimenziók súlyszámai, valamint az ezek összegéből adó összpontszám értéke. Ennél a kérdőívnél a magasabb pontértékek alacsonyabb életminőséget jeleznek. A kérdőívet a beteg stabil állapotban az intézményben töltötte ki koordinátor felügyelete mellett. A 6 perces sétatávolság (6MWD) mérésekor a betegeket arra kértük, hogy 6 percig sétáljanak a folyosón, és ennek során detektáltuk a maximális sétatávolságot [11]. Minden beteg kitöltötte a Brit Mellkasi Társaság módosított nehézlégzésskáláját is (mMRC-dyspnoeskála), amely a terhelésre adott nehézlégzésválaszt jelöli. 5 pontban értékeltük a nehézlégzés fokát, amelyet a beteg becsült meg a gyógytornász segítségével. Az enyhe probléma: $0-1$, a közepes probléma 2 , a súlyos probléma 3-4 pontot jelentett (2. táblázat) [12].

A betegek tápláltsági állapotának vizsgálatakor a testsúly és a testmagasság múszeres felvételére került sor; a további adatok gyưjtése saját szerkesztésű kérdőívvel történt. A kérdőív rákérdezett a betegek nemére, életkorára, iskolai végzettségére, a dohányzási anamnézisre és a betegségük állapotára, az elmúlt év testsúlyingadozásaira, a betegek táplálkozására, testmozgására és tápszer-, valamint étrendkiegészítő-fogyasztási szokásaira.

Éhomi vérmintát gyújtöttünk az Országos Korányi Pulmonológiai Intézet központi laboratóriumában a szérum lipidprofiljának (teljes koleszterin, trigliceridek, LDL [low-density lipoprotein - alacsony súrúségú lipoprotein], HDL [high-density lipoprotein - magas sürüségú lipoprotein]) és a szérum CRP-szintjének (nagy érzékenységü [highly sensitive]) hs-CRP-teszttel, immunoassay módszerrel történő meghatározására (AQT90 FLEX immunoassay analizátoron; Radiometer, Koppenhága, Dánia). A vérvételi vizsgálatot a betegek klinikailag stabil, lázmentes és légúti fertőzéstől mentes állapotában végeztük.

\section{Statisztikai analízis}

A leíró elemzéseket STATA SE-10.0 (StataCorp, College Station, TX, USA) programcsomaggal végeztük. A minta eloszlását Shapiro-Wilk-teszttel ellenőriztük, a folytonos változók nem normáleloszlást mutattak, ezért medián és interkvartilis terjedelemben adtuk meg a táblázatok adatait. Nemparametrikus próbát (KruskalWallis-próba) alkalmaztunk a különböző csoportok öszszehasonlítására. A statisztikai teszteket 95\%-os konfidenciaintervallum mellett végeztük, a szignifikancia értéke $\mathrm{p}<0,05$ volt.

\section{Eredmények}

A betegek medián életkora 66 (IQR 60-73) év volt, a nemi megosztást tekintve $47,5 \%$ férfi és $52,5 \%$ nő. A medián BMI 26,0 (IQR 21,7-30,6) kg/m² a medián $\mathrm{FEV}_{1}$ (ref\%) 48,0 (IQR 38,1-55,3) volt. A valaha $(51,3 \%)$ és 
3. táblázat Ómega-3 többszörösen telítetlen zsírsavakat fogyasztó és nem fogyasztó COPD-s betegek összehasonlítása és értékelése a tüdőfunkcióval és antropometriai paraméterekkel

\begin{tabular}{|c|c|c|c|}
\hline & Ómega-3 zsírsavakat fogyasztó & Ómega-3 zsírsavakat nem fogyasztó & p-érték \\
\hline & $(\mathrm{n}=19)$ & $(\mathrm{n}=381)$ & \\
\hline Férfi (fö, \%) & $10(52,63)$ & $180(42,24)$ & 0,646 \\
\hline Nő (fö, \%) & $9(43,37)$ & $201(52,75)$ & \\
\hline Kor (év) (IQR) & $64(57-72)$ & $67(61-73)$ & 0,541 \\
\hline $\mathrm{CRP}(\mathrm{mg} / \mathrm{l})$ & $6,5(1,2-13,5)$ & $8,4(2,4-26,6)$ & 0,081 \\
\hline \multicolumn{4}{|l|}{ Dohányzási status } \\
\hline Aktívan dohányzó (fó, \%) & $6(31,58)$ & $168(44,09)$ & 0,272 \\
\hline Leszokott (f”, \%) & $12(63,16)$ & $193(50,66)$ & \\
\hline Nem dohányzott (fó, \%) & $1(5,26)$ & $20(5,25)$ & \\
\hline Dohányzás (év) & $40(26-46)$ & $40(27-48)$ & 0,664 \\
\hline A cigaretták száma (szál/nap) & $20(13-20)$ & $20(17-25)$ & 0,273 \\
\hline BMI $\left(\mathrm{kg} / \mathrm{m}^{2}\right)$ & $28,2(22,1-35,2)$ & $24,7(21,4-30,0)$ & 0,118 \\
\hline Összkoleszterin $(\mathrm{mmol} / \mathrm{l})$ & $5,0(4,2-5,7)$ & $5,1(4,5-6,0)$ & 0,565 \\
\hline LDL-koleszterin & $2,9(2,2-3,3)$ & $2,9(2,4-3,4)$ & 0,826 \\
\hline HDL-koleszterin & $1,5(1,1-1,7)$ & $1,3(1,0-1,6)$ & 0,328 \\
\hline Triglicerid (mmol/l) & $1,6(1-2)$ & $1,5(1-1,8)$ & 0,646 \\
\hline $\mathrm{FEV}_{1}(\operatorname{ref} \%)$ & $49(39-56)$ & $46(42-63)$ & 0,407 \\
\hline FVC (\%) & $72(62-86)$ & $70(58-83)$ & 0,386 \\
\hline $\mathrm{FEV}_{1} / \mathrm{FVC}(\%)$ & $56(45-60)$ & $51(42-63)$ & 0,631 \\
\hline \multicolumn{4}{|l|}{ GOLD-csoportok } \\
\hline GOLD A (f", \%) & $2(10,53)$ & $115(30,18)$ & 0,052 \\
\hline GOLD B (f”, \%) & $7(36,84)$ & $219(57,48)$ & \\
\hline GOLD C (f", \%) & $9(47,37)$ & $42(11,03)$ & \\
\hline GOLD D (f”, \%) & $1(5,26)$ & $5(1,31)$ & \\
\hline \multicolumn{4}{|l|}{ Társbetegségek (n, \%) } \\
\hline Hypertonia & $10(52,63)$ & $275(72,18)$ & 0,066 \\
\hline Diabetes mellitus & $3(15,79)$ & $88(23,09)$ & 0,458 \\
\hline Metabolikus szindróma & $7(36,84)$ & $222(58,26)$ & 0,065 \\
\hline Pszichiátriai betegség & $1(5,26)$ & $49(12,86)$ & 0,328 \\
\hline \multicolumn{4}{|l|}{ mMRC-dyspnoeskála (n, \%) } \\
\hline 0. & $5(26,31)$ & $39(10,23)$ & 0,039 \\
\hline 1. & $6(31,59)$ & $120(31,49)$ & \\
\hline 2. & $4(21,05)$ & $66(17,33)$ & \\
\hline 3. & $3(15,79)$ & $57(14,97)$ & \\
\hline 4. & $1(5,26)$ & $99(25,98)$ & \\
\hline SGRQ-C: tünet & $48,7(33,9-62,4)$ & $56,8(44,4-72,7)$ & 0,046 \\
\hline SGRQ-C: aktivitás & $35,5(30,3-48,0)$ & $46,5(31,3-59,9)$ & 0,050 \\
\hline SGRQ-C: hatás & $65,1(46,2-78,6)$ & $68,4(54,5-79,1)$ & 0,548 \\
\hline SGRQ-C: teljes & $65,8(52,4-79,7)$ & $72,2(56,2-88,6)$ & 0,044 \\
\hline 6MWD (m) & $300(177-387)$ & $251(150-345)$ & 0,121 \\
\hline \multicolumn{4}{|l|}{ COPD-fellángolás (n, \%) } \\
\hline$\geq 2$ & $5(26,31)$ & $198(51,97)$ & 0,029 \\
\hline$<2$ & $14(73,69)$ & $183(48,03)$ & \\
\hline
\end{tabular}

A táblázat adatai medián és interkvartilis terjedelemben kerültek bemutatásra.

$6 \mathrm{MWD}=6$ perces sétatávolság; $\mathrm{BMI}=$ testtömegindex; $\mathrm{COPD}=$ krónikus obstruktív tüdőbetegség; $\mathrm{FEV}_{\mathrm{l}}=$ erőltetett kilégzés első másodpercében kifújt volumen; FVC = erőltetett kilégzési vitálkapacitás; GOLD = a COPD ellen küzdő nemzetközi ajánlás; HDL = magas sưrúségú lipoprotein; LDL = alacsony sűrűségü lipoprotein; $\mathrm{mMRC}=$ a Brit Mellkasi Társaság módosított nehézlégzésskálája; SGRQ-C = Szent György Légzési Kérdőív COPD-s betegek számára

Szignifikanciaszint: $\mathrm{p}<0,05$ 
jelenleg is $(43,5 \%)$ dohányzó $(94,8 \%)$ betegek átlagosan 40 éven át 20 szál/nap cigarettát szívtak el. A betegek legmagasabb iskolai végzettsége 43\%-ban általános iskolai, 42\%-ban középiskolai/szakközépiskolai és 15\%-ban fóiskolai/egyetemi volt. Az ómega-3 többszörösen telítetlen zsírsavat fogyasztó betegek több mint fele középiskolai/szakközépiskolai végzettségü volt $(\mathrm{n}=13)$.

Az ómega-3 zsírsavakat fogyasztó betegek körében ( $\mathrm{n}=19)$ alacsonyabb szérum-CRP-szintet mértünk (IQR 6,5 [1,2-13,5] vs. 8,4 [2,4-26,6]; p = 0,081) és kedvezőbb lipidprofilt (teljes koleszterin, trigliceridek, LDL- és HDL-koleszterin) detektáltunk magasabb BMI-érték (IQR 28,2 [22,1-35,2] vs. 24,7 [21,4-30,0]; $\mathrm{p}=0,118)$ mellett, mint az ómega-3-pótlásban nem részesülő betegeknél $(\mathrm{n}=381)$. Az ómega-3 többszörösen telítetlen zsírsavakat fogyasztó $(4,7 \%)$ és nem fogyasztó (95,3\%) COPD-s betegek összehasonlítását és értékelését a tüdőfunkcióval és a különböző antropometriai paraméterekkel a 3. táblázat tartalmazza. A csoportosítás nem, kor, dohányzási előzmények, tápláltsági állapot (BMI), lipidprofil (teljes koleszterin, trigliceridek, LDL-, HDL-koleszterin), életminőség (SGRQ-C), 6MWD, valamint az előző évi fellángolások száma alapján történt.

Az mMRC-dyspnoeskála pontszámai $(\mathrm{p}=0,039)$ és az életminőség pontszámai $(65,8[52,4-79,7]$ vs. 72,2 $[56,2-88,6] ; \mathrm{p}=0,044)$ is szignifikánsan jobbak volt az ómega-3 zsírsavakat rendszeresen fogyasztók körében. Az előzó évi fellángolások száma magasabb volt (1 [1-3] vs. $2[1-4] ; \mathrm{p}=0,029)$ az ómega-3-pótlásban nem részesülő betegek körében. A társbetegségek vonatkozásában (hypertonia, diabetes mellitus, metabolikus szindróma, pszichiátriai betegségek) alacsonyabb előfordulási gyakoriságot tapasztaltunk az ómega-3 többszörösen telítetlen zsírsavakat rendszeresen szedő betegek között (3. táblázat). A 6MWD medián értéke (300 [177-387] vs. 251 [150-345]; $\mathrm{p}=0,121$ ) volt az ómega-3 zsírsavakat fogyasztó és nem fogyasztó csoportot összehasonlítva.

A vizsgált COPD-s betegeket GOLD A (7,5\%), GOLD B $(30,0 \%)$, GOLD C $(45,2 \%)$ és GOLD D (17,3\%) kategóriákba soroltuk; az előrehaladottabb, súlyosabb stádiumú betegek (GOLD C, D) magasabb CRP-szinttel rendelkeztek, mint az enyhébb stádiumba (GOLD A, B) soroltak (4. táblázat). Az ómega-3 többszörösen telítetlen zsírsavakat rendszeresen fogyasztó betegek többsége a GOLD B $(\mathrm{n}=7)$ és a GOLD C $(n=9)$ csoportba került. A betegek az ómega-3 zsírsavakat a kezelőorvosuk javaslatára vásárolták közforgalmú gyógyszertárban, és rendszeresen szedték az előző 6 hónapban, az orvos által javasolt napi dózisban $(0,25-0,50$ $\mathrm{g} /$ nap).

Az 5. táblázat a vizsgált COPD-s betegek hörgötágító gyógyszereit tartalmazza, ómega-3 többszörösen telítetlen zsírsavakat fogyasztó és nem fogyasztó csoportokra bontva. Az ómega-3 zsírsavakat rendszeresen fogyasztó betegek kevesebb gyógyszert használtak, a gyors hatású béta-2-agonisták tekintetében a különbség szignifikáns volt $(5[25,31]$ vs. $197[51,71] ; \mathrm{p}=0,03)$.

Arra a kérdésünkre, hogy milyen táplálékot fogyasztanak szívesen, a legtöbben a húst válaszolták, ezt követően a zöldségeket, a gyümölcsöket, az olajos magvakat, a fózelékeket és a halakat jelölték meg; a résztvevők több mint fele $(52,3 \%)$ egyáltalán nem fogyaszt halat. Ez azt jelenti, hogy az ómega-3 többszörösen telítetlen zsírsavakban gazdag ételek nagyon alacsony arányban vannak jelen a COPD-s betegek étrendjében.

4. táblázat |A betegek súlyossági osztályozása és ennek megfelelően a paraméterek összehasonlítása a GOLD-stádiumok szerint

\begin{tabular}{|c|c|c|c|c|c|}
\hline & GOLD A & GOLD B & GOLD C & GOLD D & p-érték \\
\hline & $(\mathrm{n}=30)$ & $(\mathrm{n}=120)$ & $(\mathrm{n}=181)$ & $(\mathrm{n}=69)$ & \\
\hline Kor (év) (IQR) & $64(59-64)$ & $67(61-74)$ & $68(63-72)$ & $65(60-69)$ & 0,167 \\
\hline Férfi (fö, \%) & $10(33,33)$ & $58(48,33)$ & $82(45,3)$ & $40(57,97)$ & 0,117 \\
\hline Nő (fö, \%) & $20(66,67)$ & $62(51,67)$ & $99(54,7)$ & $22,2(42,03)$ & \\
\hline BMI $\left(\mathrm{kg} / \mathrm{m}^{2}\right)$ & $28,0(23,7-32,6)$ & $24,8(22,3-24,8)$ & $24,4(20,8-29,7)$ & $22,2(19,2-27,4)$ & $<0,001$ \\
\hline $6 \mathrm{MWD}(\mathrm{m})$ & $300(178-363)$ & $287(202-287)$ & $250(150-325)$ & $235(130-300)$ & $<0,001$ \\
\hline $\mathrm{FEV}_{1}(\mathrm{ref} \%)$ & $92(84-92)$ & $62(54--69)$ & $42(36-46)$ & $24(21-26)$ & $<0,001$ \\
\hline FVC (\%) & $108(100-108)$ & $81(70-90)$ & $67(59-76)$ & $49(43-55)$ & $<0,001$ \\
\hline $\mathrm{CRP}(\mathrm{mg} / \mathrm{l})$ & $3,6(1,7-3,6)$ & $4,7(1,7-15,1)$ & $6,5(2,1-15,6)$ & $12,1(4,1-26,6)$ & 0,077 \\
\hline Ómega-3 (fö, \%) & $2(10,5)$ & $7(36,8)$ & $9(47,4)$ & $1(5,3)$ & 0,456 \\
\hline
\end{tabular}

A táblázat adatai medián és interkvartilis terjedelemben kerültek bemutatásra.

$6 \mathrm{MWD}=6$ perces sétatávolság; $\mathrm{BMI}=$ testtömegindex; $\mathrm{CRP}=\mathrm{C}$-reaktív protein; $\mathrm{FEV}_{1}=$ erőltetett kilégzés első másodpercében kifújt volumen; FVC = erőltetett kilégzési vitálkapacitás; GOLD = a COPD ellen küzdő nemzetközi ajánlás; IQR = interkvartilis tartomány

Szignifikanciaszint: $\mathrm{p}<0,05$ 
5. táblázat A vizsgált COPD-s betegek által használt hörgőtágító gyógyszerek ómega-3 zsírsavakat fogyasztó és nem fogyasztó csoport bontásban

\begin{tabular}{llll}
\hline & $\begin{array}{l}\text { Ómega-3 } \\
\text { zsírsavakat } \\
\text { fogyasztó }\end{array}$ & $\begin{array}{l}\text { Ómega-3 } \\
\text { zsírsavakat nem } \\
\text { fogyasztó }\end{array}$ & p-érték \\
\hline Gyógyszerek $(\mathrm{n}, \%)$ & $(\mathrm{n}=19)$ & $(\mathrm{n}=381)$ & \\
\hline SABA & $5(25,31)$ & $197(51,71)$ & 0,031 \\
LAMA & $2(10,52)$ & $80(20,99)$ & 0,269 \\
LABA & $1(5,26)$ & $45(11,81)$ & 0,382 \\
LABA + LAMA & $1(5,26)$ & $33(8,66)$ & 0,604 \\
ICS + LABA & $2(10,52)$ & $52(13,64)$ & 0,697 \\
LABA + LAMA + ICS & $4(21,05)$ & $93(24,42)$ & 0,738 \\
Teofillinnel kombinálva & $7(36,84)$ & $151(39,63)$ & 0,808 \\
\hline
\end{tabular}

COPD = krónikus obstruktív tüdőbetegség; ICS = inhalációs kortikoszteroid; LABA = hosszú hatású béta-2-agonista; LAMA = hosszú hatású muszkarinerg-antagonista; $\mathrm{SABA}$ = rövid hatású béta-2-agonista

Szignifikanciaszint: $\mathrm{p}<0,05$

\section{Megbeszélés}

Kutatásunkban az ómega-3-pótlás klinikai értékét és gyulladáscsökkentő hatását vizsgáltuk COPD-s betegeknél. Eredményeink azt sugallják, hogy a többszörösen telítetlen zsírsavak bevitele összefüggésben lehet a szokásos napi fizikai aktivitással és az életminőséggel is. Megállapítottuk, hogy a többszörösen telítetlen zsírsavakkal való táplálékkiegészítés pozitív kapcsolatot mutat a betegek légzésfunkciójával, a gyulladásos paraméterekkel, a lipidprofillal, a társbetegségekkel, a hörgőtágító gyógyszerek alkalmazásával és az előző évi fellángolások számával is. A legújabb GOLD-ajánlás a fizikai aktivitás monitorozására a 6MWD mérését ajánlja a pulmonalis rehabilitáció hatékonyságának értékeléséhez: ez kulcsfontosságú a COPD-s betegek számára a kezelésükben $[9,13]$, tekintettel arra, hogy a fizikai aktivitás határozottan megjósolja a COPD-ben szenvedő betegek mortalitását $[14,15]$; kutatásunkban ez a paraméter is pozitív kapcsolatban állt az ómega-3 zsírsavak bevitelével.

Szükség van új gyulladáscsökkentő stratégiák kidolgozására, mivel egyetlen szer - ideértve a kortikoszteroidokat is - nem képes lassítani a COPD krónikusan progrediáló gyulladásos folyamatát $[16]$. Az ómega-3 zsírsavakban gazdag étrend, valamint a többszörösen telítetlen zsírsavak pótlása is gyulladáscsökkentő hatással bír, és javítja a betegek terhelési toleranciáját [17]. Számos korábbi tanulmány leírta, hogy a többszörösen telítetlen zsírsavak bevitele javítja a betegek életminőségét. Az ómega-3-kiegészítésben részesülő betegek képesek voltak csökkenteni a nemszteroid gyulladáscsökkentố gyógyszerek dózisát rheumatoid arthritisben, szisztémás lupus erythematosusban, lupus nephritisben és osteoarthritisben is [18-21]. Egy randomizált kontrollált vizsgálat kimutatta, hogy napi l,0 g PUFA-kiegészítéssel csökkenthetők a menstruáció előtti tünetek, és javul az élet- minőség is [22]. Egy másik, kettős vak-, randomizált kontrollált vizsgálat 3,0 g/nap ómega-3-kiegészítéssel három hónapon keresztül számos gyulladásos marker csökkenését és az életminőség javulását mutatta ki krónikus hemodializált betegekben [23]. Az ómega-3 zsírsavak szupplementációja pozitív hatással lehet a COPDben szenvedő betegekre is, hiszen a COPD légúti és szisztémás gyulladásos betegség, és az ómega-3 lassíthatja ezt a gyulladásos folyamatot, javulhat az életminőség [24]. A többszörösen telítetlen zsírsavak adása csökkentette a szérum-CRP értékét is $[25,26]$.

Vizsgálatunkban az ómega-3 zsírsavakat rendszeresen szedő betegek esetében alacsonyabb szérum-CRP-szintet detektáltunk, és szignifikánsan jobb életminőséget. Az ómega-3 zsírsavak előnyös hatásai között a legismertebbek: gátolják a gyulladást és a tumornövekedést, továbbá az arachidonsavból származó prosztaglandinok és leukotriének keletkezését, valamint a proliferációt, és elósegítik az apoptózist az emlö-, a prosztata- és a vastagbélrák-sejtvonalakban $[27,28]$.

Az American Heart Association az étrend kiegészítését javasolja ómega-3 többszörösen telítetlen zsírsavakkal [29], mivel ezek a zsírsavak csökkentik a szív- és érrendszeri betegségek elófordulási gyakoriságát [30]. A PUFA-val való étrend-kiegészítés antiatheroscleroticus hatásának alapja az apoCIII-koncentrációnak és a lipoprotein-lipáz-termelésnek, továbbá a plazma triglicerid-, VLDL-koleszterin- és VLDL-triglicerid-koncentrációjának a csökkenése, a HDL-koleszterin-szint növekedése és a sejtmembrán foszfolipid-összetételének változása [31]. A hosszú szénláncú ómega-3 zsírsavak (EPA, DHA) ajánlott bevitele szív- és érrendszeri betegségek megelőzésére $0,3-0,5 \mathrm{~g} / \mathrm{nap}$. E betegségek fokozott kockázata esetén $1,0 \mathrm{~g}$ bevitele javasolt, emelkedett trigliceridszint esetén pedig $2,0-4,0 \mathrm{~g} / \mathrm{nap}$. Több, követéses tanulmányban leírták, hogy akik napi $1,0 \mathrm{~g}$ ómega-3 zsírsavat fogyasztottak, és már több, gyógyszeres kezelésen átestek (thrombocytaaggregációt gátló szerek, vérzéscsillapítók, koleszterin- és trigliceridcsökkentő szerek), azoknál a halolaj volt a leghatékonyabb az infarktus prevenciójában $[32,33]$.

Számos kutató jelezte az ómega-3 zsírsavak gyulladáscsökkentő hatását COPD-ben is; a fertőzések megelőzésében és kezelésében is hatásosak. A kutatók szerint az ómega-3 zsírsavakban gazdag étrend „biztonságos és praktikus módszer a COPD kezelésében”. Eset-kontroll vizsgálatban bizonyították, hogy aki kapott ómega-3-kiegészítést $(0,5-1,0 \mathrm{~g} / \mathrm{nap})$, annál kevesebb volt a fertőzéses szövődmény és magasabb a 6MWD értéke [34-36]. A többszörösen telítetlen zsírsavaknak pozitívak a cardialis hemodinamikai hatásaik, növekszik a szív oxigénellátása, javul a dyastolés funkció és a légzésfunkció, csökken a terhelés indukálta bronchoconstrictio [37]. Egy randomizált, kettős vakvizsgálatban élsportolóknál a diéta háromhetes kiegészítése PUFA-gazdag halolajjal $(1,0 \mathrm{~g} / \mathrm{nap})$ a sportolókban jelentősen csökkentette a terhelés indukálta bronchoconstrictiót [38, 39]. 


\section{A vizsgálat korlátai}

Vizsgálatunk hátránya, hogy keresztmetszeti megfigyeléses vizsgálat volt, az ok-okozati összefüggés nem egyértelmû. COPD-s betegeknél megfigyeltük, hogy a többszörösen telítetlen zsírsavak bevitele jobb lipidprofillal, jobb légzésfunkcióval és szignifikánsan jobb életminőséggel jár együtt, de további randomizált, követéses vizsgálatokra van szükség a többszörösen telítetlen zsírsavak egészséggel kapcsolatos előnyeinek tisztázására. További tanulmányokban érdekes lehet annak vizsgálata, hogy a nagy adagú ómega-3-mal való étrend-kiegészítés milyen hatást gyakorol a COPD kezelésére.

\section{Következtetés}

Megvizsgáltuk a többszörösen telítetlen zsírsavak bevitelének gyakoriságát, a tüdőfunkcióval és az életminőséggel kapcsolatos összefüggéseket COPD-s betegekben, és megállapítottuk, hogy a többszörösen telítetlen zsírsavak pótlása pozitív kapcsolatot mutat a betegek fizikai aktivitásával, a gyulladásos paraméterekkel, a fellángolások számával, a légzést segítő gyógyszerek szedésével és az életminőséggel is. Megfigyelt adataink alátámasztják azt a hipotézist, miszerint az ómega-3 zsírsavak adása hatékony és biztonságos gyulladáscsökkentő stratégia lehet a COPD kezelésében.

Anyagi támogatás: A szerző́k a cikk megírása, illetve a kutatómunka során anyagi támogatásban nem részesültek.

Szerzői munkamegosztás: F. M., N. A. N.: A kérdőív szerkesztése, a kérdő́ivek feldolgozása, értékelése, irodalomkutatás, cikkírás. Sz. G.: A statisztika ellenőrzése, cikkírás. V. J. T.: A kutatás felügyelete, a kézirat megszövegezése, ellenőrzése, végső formába öntése. A cikk végleges változatát valamennyi szerző elolvasta és jóváhagyta.

Érdekeltség: A szerzőknek nincsenek érdekeltségeik.

\section{Irodalom}

[1] Varga JT. Chronic obstructive pulmonary disease. [Krónikus obstruktív tüdőbetegség.] Háziorv Továbbk Szle. 2018; 23: 5458. [Hungarian]

[2] Varga J, Casaburi R, Ma S, et al. Relation of concavity in the expiratory flow-volume loop to dynamic hyperinflation during exercise in COPD. Respir Physiol Neurobiol. 2016; 234: 79-84.

[3] Varga JT. Smoking and pulmonary complications: respiratory prehabilitation. J Thorac Dis. 2019; 11(Suppl 5): S639-S644.

[4] Fehér J, Kovács I, Corrado BG. Cod liver oil. A natural Vitamin $\mathrm{D}$ for preserving health. [Csukamájolaj. Egy természetes D-vitamin az egészség megőrzésére.] Orv Hetil. 2011; 152: 323-330. [Hungarian]

[5] Böszörményi Nagy Gy, Balikó Z, Kovács G, et al. Guideline for the diagnosis and treatment of chronic obstructive pulmonary disease (COPD) in primary care, specialist- and emergency care.
[Egészségügyi szakmai irányelv a krónikus obstruktív tüdőbetegség (COPD) diagnosztikájáról és kezeléséről az alap-, a szak- és a sürgősségi ellátás területére.] Med Thorac. 2014; 67(Suppl): 79-113. Available from: https://www.copdplatform.com/res/file/national-documents/hun-guidelines.pdf [accessed: June 14, 2020]. [Hungarian]

[6] Broekhuizen R, Wouters EF, Creutzberg EC, et al. Polyunsaturated fatty acids improve exercise capacity in chronic obstructive pulmonary disease. Thorax 2005; 60: 376-382.

[7] Lemoine S CM, Brigham EP, Woo H, et al. Omega-3 fatty acid intake and prevalent respiratory symptoms among U.S. adults with COPD. BMC Pulm Med. 2019; 19: 97.

[8] Kris-Etherton PM, Innis S, American Dietetic Association, Dietitians of Canada. Position of the American Dietetic Association and Dietitians of Canada: dietary fatty acids. J Am Diet Assoc. 2007; 107: 1599-1611.

[9] Singh D, Agusti A, Anzueto A, et al. Global strategy for the diagnosis, management, and prevention of chronic obstructive lung disease: the GOLD science committee report 2019. Eur Respir J. 2019; 53: 1900164.

[10] Jones PW, Quirk FH, Baveystock CM, et al. A self-complete measure for health status for chronic airflow limitation. The St. George's Respiratory Questionnaire. Am Rev Respir Dis. 1992; 145: 1321-1327

[11] ATS Committee on Proficiency Standards for Clinical Pulmonary Function Laboratories. ATS statement: guidelines for the sixminute walk test. Am J Respir Crit Care Med. 2002; 166: 111117.

[12] Launois C, Barbe C, Bertin E, et al. The modified Medical Research Council scale for the assessment of dyspnea in daily living in obesity: a pilot study. BMC Pulm Med. 2012; 12: 61.

[13] Vágvölgyi A, Rozgonyi Z, Vadász P, et al. Risk stratification before thoracic surgery, perioperative pulmonary rehabilitation. [A mellkassebészeti mútéti teherbíró képesség megítélése, perioperatív légzésrehabilitáció.] Orv Hetil. 2017; 158: 1989-1997. [Hungarian]

[14] Varga JT. Smoking and pulmonary complications: respiratory prehabilitation. J Thorac Dis. 2019; 11: S639-S644.

[15] Fekete M, Pongor V, Fehér A, et al. Relationship of chronic obstructive pulmonary disease and nutritional status - clinical observations. [Krónikus légzőszervi betegek tápláltsági állapotának vizsgálata - klinikai megfigyelések.] Orv Hetil. 2019; 160: 908913. [Hungarian]

[16] Kerti M, Balogh Zs, Varga JT. New treatments in pulmonological physiotherapy. [Új eszközök a pulmonológiai fizikoterápiában.] Med Thorac. 2015; 68: 200-205. [Hungarian]

[17] Varga JT, Szilasi M. Handbook of pulmonary rehabilitation. [A pulmonológiai rehabilitáció kézikönyve.] SpringMed Kiadó, Budapest, 2018. [Hungarian]

[18] Fehér J, Kovács I, Balacco Gabrieli C. Role of gastrointestinal inflammations in the development and treatment of depression. [A krónikus gyomor-bél gyulladások szerepe a depresszió kialakulásában és kezelésében.] Orv Hetil. 2011; 152: 1477-1485. [Hungarian]

[19] Navarini L, Afeltra A, Gallo Afflitto G, et al. Polyunsaturated fatty acids: any role in rheumatoid arthritis? Lipids Health Dis. 2017; 16: 197

[20] Pestka JJ. n-3 polyunsaturated fatty acids and autoimmune-mediated glomerulonephritis. Prostaglandins Leukot Essent Fatty Acids 2010; 82: 251-258.

[21] Hegedús B, Varga J, Somfay A. Interdisciplinary rehabilitation in patients with ankylosing spondylitis. [Az interdiszciplináris rehabilitáció hatása spondylitis ankylopoeticában szenvedő betegekben.] Orv Hetil. 2016; 157: 1126-1132. [Hungarian]

[22] Behboudi-Gandevani S, Hariri FZ, Moghaddam-Banaem L. The effect of omega 3 fatty acid supplementation on premenstrual syndrome and health-related quality of life: a randomized clinical trial. J Psychosom Obstet Gynaecol. 2018; 39: 266-272. 
[23] Moeinzadeh F, Shahidi S, Mortazavi M, et al. Effects of omega-3 fatty acid supplementation on serum biomarkers, inflammatory agents, and quality of life of patients on hemodialysis. Iran J Kidney Dis. 2016; 10: 381-387.

[24] Varga JT. Theoretical and practical foundations of respiratory rehabilitation. Locations of care. [A légzésrehabilitáció elméleti és gyakorlati alapjai. Ellátási színterek.] Korányi Bull. 2016; (1): 44-47. [Hungarian]

[25] Varga Zs. Cardioprotective role omega-3 polyunsaturated fatty acids. [Az omega-3 többszörösen telítetlen zsírsavak az atherosclerosis megelőzésében.] Orv Hetil. 2008; 149: 627-637. [Hungarian]

[26] Márton J, Farkas G, Nagy Z, et al. Plasma levels of TNF and IL-6 following induction of acute pancreatitis and pentoxifylline treatment in rats. Acta Chir Hung. 1997; 36: 223-225.

[27] Fuentes NR, Kim E, Fan YY, et al. Omega-3 fatty acids, membrane remodeling and cancer prevention. Mol Aspects Med. 2018; 64: 79-91.

[28] Németh E, Fehér J, Nagy V, et al. The role of antioxidants in prevention. [Antioxidánsok szerepe a prevencióban.] Orv Hetil. 2006; 147: 603-607. [Hungarian]

[29] Kris-Etherton PM, Harris WS, Appel LJ, for the Nutrition Committee. Fish consumption, fish oil, omega-3 fatty acids, and cardiovascular disease. Circulation 2002; 106: 2747-2757.

[30] Fehér J, Lengyel G. Nutrition and cardiovascular mortality. [Táplálkozás és a szív- és érrendszeri betegségek miatti halálozás.] Orv Hetil. 2006; 147: 1491-1496. [Hungarian]

[31] Siscovick DS, Raghunathan TE, King I, et al. Dietary intake and cell membrane levels of long-chain $\mathrm{n}-3$ polyunsaturated fatty acids and the risk of primary cardiac arrest. JAMA 1995; 274: 1363-1367.

[32] Kiss O, Sydó N, Merkely B. Favourable effects of omega-3 fatty acid dietary supplementation in athletes. $[\mathrm{Az}$ omega-3 zsírsay étrend-kiegészítés kedvező hatásai sportolókban.] Cardiol Hung. 2012; 42: 312-316. [Hungarian]

[33] Walz CP, Barry AR, Koshman SL. Omega-3 polyunsaturated fatty acid supplementation in the prevention of cardiovascular disease. Can Pharm J (Ott). 2016; 149: 166-173.

[34] Wood LG. Omega-3 polyunsaturated fatty acids and chronic obstructive pulmonary disease. Curr Opin Clin Nutr Metab Care 2015; 18: 128-132.

[35] Lemoine S CM, Brigham EP, Woo H, et al. Omega-3 fatty acid intake and prevalent respiratory symptoms among U.S. adults with COPD. BMC Pulm Med. 2019; 19: 97.

[36] Gold DR, Litonjua AA, Carey VJ, et al. Lung VITAL: Rationale, design, and baseline characteristics of an ancillary study evaluating the effects of vitamin D and/or marine omega-3 fatty acid supplements on acute exacerbations of chronic respiratory disease, asthma control, pneumonia and lung function in adults. Contemp Clin Trials 2016; 47: 185-195.

[37] Varga J, Pórszász J, Boda K, et al. Supervised high intensity continuous and interval and home training effect in the rehabilitation of chronic obstructive pulmonary patients. [Felügyelt magas intenzitású folyamatos és intervallum, valamint otthoni tréning hatásának vizsgálata krónikus obstruktív tüdőbetegek rehabilitációjában.] Med Thorac. 2008; 61: 135-143. [Hungarian]

[38] Gammone MA, Riccioni G, Parrinello G, et al. Omega-3 polyunsaturated fatty acids: benefits and endpoints in sport. Nutrients 2018; $11: 46$.

[39] Endre L. Physical exercise and bronchial asthma. [A testedzés és az asztma kapcsolata.] Orv Hetil. 2016; 157: 1019-1027. [Hungarian]

(Fekete Mónika dr., Budapest, Nagyvárad tér 4., 1089 e-mail: fekete.monika@med.semmelweis-univ.hu)

\section{"Gravius nocet quodcumque inexpertum accidit." (Ha váratlan a baj, még többet árt.)}

A cikk a Creative Commons Attribution 4.0 International License (https://creativecommons.org/licenses/by/4.0/) feltételei szerint publikált Open Access közlemény, melynek szellemében a cikk bármilyen médiumban szabadon felhasználható, megosztható és újraközölhető, feltéve, hogy az eredeti szerző és a közlés helye, illetve a CC License linkje és az esetlegesen végrehajtott módosítások feltüntetésre kerülnek. (SID_1) 